\title{
Tapuias, entre cronistas e hommes de lettres: análise comparativa da historiografia brasileira nos séculos $\mathrm{XVI}$ e XIX
}

\section{Sonielson Juvino Silva*}

sonielsonsilva@vol.com.br

\begin{abstract}
Resumo
$\mathrm{O}$ artigo se propõe discutir os distintos significados que o termo indígena Tapuia assumiu ao longo do tempo no Brasil, tendo por base a análise comparativa de dois momentos específicos: o final do século XVI, com os primeiros cronistas, e a segunda metade do século XIX, com os hommes de lettres e os literatos românticos. A abordagem tem como suporte teórico os conceitos de "espaço de experiência" e "horizonte de expectativa", propostos por Reinhart Koselleck para se entender os diferentes tempos históricos. O estudo perpassa, também, pela visão dualista com que o índio brasileiro é percebido pela historiografia tradicional.
\end{abstract}

\section{Palavras-chave}

História; Brasil; Século XVI; Índios; Tapuia; Linguagem.

Tapuias, between chroniclers and hommes de lettres: comparative analysis of Brazilian historiography in the 16th and 19th centuries

\begin{abstract}
The article aims to discuss the different meanings that the indigenous term Tapuia assumed over time in Brazil, based on the comparative analysis of two specific moments: the end of the sixteenth century, with the first chroniclers, and the second half of the nineteenth century, with the hommes de lettres and the romantic literati. The approach has as theoretical support the concepts of Space of experience"and horizon of expectation," proposed by Reinhart Koselleck to understand the different historical times. The study also pass through the dualistic view with which the Brazilian Indian is perceived by traditional historiography.
\end{abstract}

\section{Keywords}

History; Brazil; 16th Century; Indians; Tapuia; Language 


\section{Introdução}

“O passado é um país estrangeiro: lá, as coisas são feitas de maneira diferente". Esta frase, que inicia um romance do escritor inglês L. P. Hartley (2002, p. 7), tornou-se preciosa para a historiografia recente, vindo a ser utilizada até como título de livro de um historiador conhecido $^{1}$. Isso porque, com relação ao passado, um lugar estranho e afastado no tempo, só podemos fazer interpretações e, mesmo assim, a partir do momento atual, uma vez que o presente é a única duração que o historiador conhece (REIS, 2012, p. 45.).

De acordo com Koselleck (2006, p. 305-313), ao se embrenhar nos difíceis caminhos do não vivido, o historiador se move inevitavelmente por meio de duas categorias históricas, relacionadas ao seu próprio espaço-tempo, que são a "experiência" e a "expectativa". Para o autor, o contato com os vestígios históricos envolvem não apenas questões racionais, mas também dimensões inconscientes, como recordações, desejos, esperanças e inquietações. Dessa forma, existiria entre o "espaço de experiência", as vivências e lembranças do historiador, e o "horizonte de expectativas", a reelaboração que ele faz das fontes estudadas para produzir uma espera possível, uma relação de desigualdade de cuja tensão resultaria o "tempo histórico". Dito de outra maneira: esse embate, reconfigurado a cada momento, provoca o surgimento de novas respostas e novas soluções.

É ainda Koselleck (2006, p. 11) que informa que o termo "História", com inicial maiúscula e no singular, só se destacou das "histórias", narrativas particulares e desconectadas entre si, em meados do século XVIII. A História, então, assumia o significado não apenas da sequência dos acontecimentos, mas também do seu relato. Surge daí a pergunta: escritos históricos anteriores constituiriam também obras historiográficas?

Cordeiro (2015, p. 3-4) entende que sim, pelo menos se forem considerados alguns eruditos europeus, a partir do século XVI, cuja preocupação com a objetividade e o cuidado com as fontes, elementos caros à tradição moderna e cientificista inaugurada com a Revolução Francesa, já apareciam. Dessa forma, diversos registros textuais do período estariam incluídos dentro da abordagem historiográfica sem maiores problemas.

No Brasil, defende a autora, a situação não seria diferente, ainda mais porque o surgimento tardio dos cursos de história, que somente ocorreu na década de 1930, fez com que não houvesse objeção em tratar como trabalho histórico toda a produção memorialística anterior, inclusive aquela dos chamados períodos colonial e império.

Entretanto, Hartog (2003, p. 11-12) alerta que, do ponto de vista da historiografia, não se pode confundir "época" com "regime de historicidade", sendo o primeiro um corte linear no tempo e o segundo uma sequência de estruturas que organizam o passado de uma forma específica. Assim, os confrontos entre as experiências e as expectativas inseridas no regime de historicidade do século XVI, por exemplo, não seriam os mesmos presentes no século XIX.

De fato, não obstante os cuidados dos eruditos com as fontes e a objetividade citados, Koselleck (2006, p. 58) identifica outros fatores que provocaram profundas mudanças no "fazer história" a partir do projeto iluminista, iniciado em fins do século XVIII com a Revolução Francesa. A história, antes ancorada no exemplo dos antigos e na tradição grego-cristã, sendo

\footnotetext{
${ }^{1}$ A frase de Hartley tornou-se título do livro: The past is a foreign country, de David Lowenthal.
} 
considerada a "mestra da vida", fortaleceu-se com o discurso científico e voltou-se para o porvir, não podendo "mais esperar conselho a partir do passado, mas sim apenas de um futuro que está por se constituir”.

Percebe-se que dois momentos de importante produção historiográfica no Brasil estão exatamente separados por essa mudança de regime historiográfico: o final do século XVI, quando cronistas - missionários, colonos ou viajantes - se preocupavam em retratar a ocupação das novas terras conquistadas pelo Império Português, e meados do século XIX, quando os chamados hommes de lettres ${ }^{2}$, os intelectuais que publicaram notadamente por meio da revista do Instituto Histórico e Geográfico Brasileiro (IHGB) ${ }^{3}$, buscavam construir um modelo de pensar a história para o novo Estado Nacional que se consolidava.

A escolha desses dois recortes temporais se deu em razão de o relato dos primeiros cronistas procurar registrar o estranhamento diante de um mundo novo em construção e, no outro extremo, os hommes de lettres buscarem um modelo historiográfico que possibilitasse sintetizar a nova identidade brasileira, não esquecendo o grupo de intelectuais, agrupados sobre a denominação genérica de "românticos", que reagiram à estratégia do IHGB.

Cabe ressaltar que, de acordo com De Certeau (2013, p. 47), toda obra "historiográfica se articula com um lugar de produção socioeconômico, político e cultural". Portanto, se temos, de um lado, eruditos ligados à Igreja ou à Corte, do outro, lidamos com intelectuais a serviço do Império, lugares sociais a partir dos quais foram escritas as tentativas de conceituação e diferenciação dos inúmeros grupos étnicos nativos, os quais aca- baram tornando-se todos "índios" na classificação estabelecida, divididos genericamente em dois grandes blocos monolíticos: os aliados e os inimigos (ALMEIDA, 2010, p. 25 e 68$)$.

Em síntese, propomos analisar comparativamente, a partir de autores dos dois tempos históricos, um constructo em especial, cuja origem etnológica ainda não é clara e que historicamente assumiu distintos significados: a palavra Tapuia, comumente associada aos índios hostis aos conquistadores.

Dessa forma, o entendimento do termo Tapuia presente em narrativas como as de Padre Anchieta, Fernão Cardim, Gabriel Soares de Souza e Pero de Magalhães de Gândavo, os dois primeiros religiosos e os outros laicos, será comparado com o sentido proposto por Francisco Adolfo Varnhagen, responsável por levar adiante o projeto do IHGB, sem prejuízo da utilização de discursos de outros estudiosos que se contrapuseram ao projeto, como o do romancista José de Alencar. Será verificado, ainda, como essas definições se relacionam com o regime historiográfico de cada tempo histórico.

Para isso, dividimos o trabalho em três partes: “Os Outros dos Outros", onde será feita uma apresentação do termo Tapuia, sua origem Tupi, e sua adoção pelos portugueses; "Os 'bárbaros' que falam a 'nãolíngua”,", quando se discutirá o conceito atribuído ao termo pelos primeiros cronistas, destacando a preocupação em segregar os nativos em duas linhagens, e "A nação dos sem nação", onde se mostrará que o propósito dos hommes de lettres era, ao contrário, relativizar a ideia da existência de nações indígenas e diluir as possíveis diferenças entre os povos nativos, muito embora se depare com a resistência da literatura romântica.

\footnotetext{
${ }^{2}$ Optamos pela denominação de "intelectuais" para os chamados "hommes de lettres" do século XIX, uma vez que a palavra "letrado" é utilizada também para designar estudiosos do século XVI, o que poderia dificultar o entendimento da análise

${ }^{3} \mathrm{~A}$ partir de agora simplesmente IHGB.
} 
Uma breve conclusão discutirá até que ponto os dados levantados se adequam à conceituação de "espaço de experiência" e "horizonte de expectativa", proposta por Koselleck.

\section{Os Outros dos Outros}

A palavra, por mais que se esforce em dizer o que se vê, jamais o que se vê se alojará no que se diz, ensina Foucault (2000, p. 12). O filósofo francês inspirou-se em um conto do argentino Jorge Luís Borges, no qual uma enciclopédia chinesa traz uma estranha taxonomia para classificar animais de um império, dividindo-os entre aqueles pertencentes ao Imperador, os cachorros soltos, os embalsamados, os fabulosos, os que de longe parecem moscas, etc. (BORGES, 2007, p. 124), ou seja, que apresentam uma necessidade racional completamente alheia à nossa lógica. Jenkins (2001, p. 57) concluiu, acertadamente, que toda definiç̧ão é arbitrária e o que pode parecer estranhíssimo para uns pode fazer todo o sentido para outros.

$\mathrm{Na}$ época da conquista da América, momento por excelência de encontro de culturas estranhas e racionalidades distintas, afirma Novaes $(1998$, p. 8) que não havia, por parte dos europeus, preocupação em interpretar o que era encontrado, ao contrário, "viam o mundo tal como aparecia para eles e não tal como ele é: não viam nas coisas as próprias coisas, mas apenas as ideias delas".

Tudo isso lembra um fato curioso contado por Todorov (1996, p. 96) envolvendo a América Central. Colombo tinha uma obsessão em (re)nomear todos os lugares que via, para, segundo ele, dar-lhes nomes "justos", mas, na verdade, tomar posse em nome do rei. Quando os espanhóis chegaram e lançaram os primeiros gritos, os maias responderam algo que, sonoramen- te, pareceu-lhes "Yucatán". Assim, ficou registrada a península de Yucatán. Sabe-se hoje que aqueles sons queriam dizer simplesmente "não estamos entendendo". Temos hoje a península de "não estamos entendendo".

Algumas reflexões, embora raras, também são conhecidas. No Brasil, os primeiros nativos que subiram à caravela de Cabral se encantaram com as contas de rosários que lhes foram apresentadas e, após colocarem no corpo, pediram que lhes dessem, apontando repetidamente para os colares e para a terra. Os portugueses, eufóricos, imaginaram logo que eles queriam trocar as contas por ouro, que era a expectativa maior que eles traziam na mente. Caminha, porém, foi comedido o suficiente para concluir: "Isto tomávamos nós por assim o desejarmos" (CAMINHA, s.d. p. 3). O desejo, portanto, apresenta-se como um péssimo tradutor.

Quando esse “diálogo" aconteceu, os nativos, que vieram a ser conhecidos por Tupi e Guarani, estavam concluindo o domínio do litoral brasileiro, com a expulsão de outros grupos para o interior (ALMEIDA, 2010, p. 33; COUTO, 1998, p. 56; FAUSTO, 1992, p. 382). Conforme Silva (1990, p. 34), "no momento mesmo que Cabral avistou o Monte Pascoal na Bahia, estes índios lutavam entre si pela posse dos melhores rios, os bons vales e as praias mais piscosas".

Vainfas (1995, p. 44) acrescenta que os tupisguaranis, na altura do século XVI, quando progressivamente haviam desalojados os seus contrários, “encontravam-se distribuídos pela bacia ParanáParaguai e o litoral, desde a lagoa dos Patos até Cananeia, caso guarani, e pela extensa faixa litorânea desde Iguape até o Ceará, caso tupi”.

Esse contato levou os portugueses a preocuparem-se em classificar os índios como inimigos ou aliados, conforme a situação imediata, reunindo esses últimos em uma mesma língua. Conforme Almeida (2010, p. 32), “a considerável homogeneidade linguística e 
cultural dos tupis facilitou o conhecimento sobre eles, mas deu margem a descrições simplistas”.

Prossegue a autora que "a designação dos grupos étnicos é bastante problemática e controvertida, sobretudo se levarmos em conta as dificuldades dos portugueses em identificar e compreender os vocábulos indígenas" (ALMEIDA, 2010, p. 34).

A inexistência de uma língua nativa escrita, aliada à extrema necessidade de constituição de rápidas alianças, levou os conquistadores a construir e desenvolver determinadas características para os nativos. Conclui Almeida que,

quando os cronistas diziam que tais indios eram amigos desses e inimigos daqueles, talvez não percebessem a influência que eles próprios já exerciam sobre essas relações e, com frequência, equivocavam-se ao utilizar tais relações como elementos definidores de características dos grupos indígenas que procuravam identificar (ALMEIDA, 2010, p. 34).

Frei Vicente Salvador (1918, p. 51-52) foi taxativo ao afirmar que todos os índios eram de cor castanha e sem barba, se distinguindo somente por "serem uns mais bárbaros do que outros (posto que todos o são assaz)". Esses "bárbaros dos bárbaros", ou “outros dos outros", deviam mesmo causar muito medo, até porque eles "moviam-se por interesses próprios, buscando alianças que melhor lhes servissem" (ALMEIDA, 2010, p. 68), inclusive com os inimigos franceses, e também não pareciam preocupados em distinguir a cruz da espada, ou seja, um padre de um soldado. Desde o desafortunado naufrágio do navio que carregava o bispo Sardinha, em 1556, quando quase todos os sobreviventes foram aprisionados e comidos em rituais indígenas, inclusive o religioso (SALVADOR, 1918, p. 156), passando pelas missões de catequese no Ceará, já no começo do século XVII, quando o Padre Francisco Pinto perdeu a vida (GARCIA, 1925, p.18), percebe-se que as prioridades, os ofícios e as hierarquias portugueses não eram compreendidos e muito menos respeitados por esses povos.

Tapuias, Tapuyas, Taphuias, Tapiias, Tapyyias, Tapujas, Tapuzas... Essas são algumas das tentativas dos primeiros cronistas em grafar um som que ouviam dos nativos de tronco Tupi, referindo-se aos oponentes deles. Porém, se a reprodução gráfica não foi um trabalho fácil, a definição do seu real sentido constituiu tarefa ainda mais custosa. Substantivo? Adjetivo? Referência genérica? Mero apelido? É claro que todas as propostas carregavam em grande escala o olhar do proponente, de nenhuma forma isento de interesses.

\section{Os 'bárbaros' que falam a 'não-língua'}

Conforme Todorov (1996, p. 143), a visão dos europeus em relação aos habitantes do Novo Mundo não era apenas de superioridade, mas também de diferença: os índios estariam em algum estágio entre os humanos e os animais. Massacres foram tantos que, em torno de 1513, um jurista que servia no México ao rei espanhol elaborou um documento de título extenso, mas que ficou conhecido por "Requerimiento", no qual propõe regras para serem observadas quando dos contatos com os nativos. Basicamente, o texto deveria ser lido previamente para os índios com informações sobre a soberania do rei e da Igreja. Se eles aceitassem a subordinação, teriam certos direitos. Caso contrário, se houvesse recusa ou se eles demorassem "maliciosamente para tomar uma decisão", estaria autorizada "a guerra de todos os lados e de todos os modos que puder", com a captura deles, incluindo mulheres e filhos, reduzindo todos à escravidão (RUBIOS, 1513). Naturalmente, se os índios não entendessem, a culpa era toda deles, que estavam "maliciosamente se demorando" a decidir. 
Esse documento serviu de referência para vários estudiosos procurarem estabelecer as bases da chamada "guerra justa", desde o teólogo Francisco de Vitória aos dominicanos Tomaz Ortiz e Bartolomé de Las Casas. Mas foi o erudito e filósofo Gines de Sepúlveda que, focando os valores dos índios, considerados naturais, resumiu em quatro pontos os argumentos para uma guerra legítima: recusa da obediência e se não restar outro recurso; banir o crime abominável de comer carne humana; evitar que inocentes morram em lutas desnecessárias entre eles; abrir caminho para a difusão da religião cristã e facilitar o trabalho dos missionários (TODOROV, 1996, p. 146-152).

A bula do Papa Pedro III, de 2 de junho de 1537, veio dirimir algumas dúvidas sobre o tema: todos os índios, e outros povos que no futuro se tenha notícia, sem distinção alguma, possuem alma e são capazes de abarcar a fé cristã, não devendo eles serem maltratados nem escravizados, decisão que confessava e buscava remediar o mal que estava sendo cometido ${ }^{4}$. Mas tal resolução tinha uma brecha: e para aqueles que resolvessem não abarcar a fé cristã?

Com relação ao Brasil, as ações de captura e escravização sistemática dos nativos tiveram incremento a partir de dois importantes eventos: a implantação do governo geral e a chegada das missões jesuítas, em 1549. Ou seja, estão diretamente ligadas ao modelo de ocupação adotado pelos portugueses, com base na cruz e na espada (HANSEN, 1998, p. 357-358; SANTOS, 1998, p. 145-162).

A tentativa de esclarecer as dúvidas veio por meio da Carta Régia de Dom Sebastião, em 1570, que, embora tardiamente, não deixa de seguir a bula papal de décadas atrás. A Lei real proíbe a escravização de índios catequisados pelos jesuítas, mas permite o combate contra os "[...] que costumam atacar os portugueses ou a outros gentios para os comerem". Como bem percebe Hansen (1998, p. 355-359), a "guerra justa" no Brasil atendia a duas funções bem definidas: "à prática catequética dos jesuítas e às práticas de escravização dos colonos".

Mas, como separar o joio do trigo? Os colonos não pareciam preocupados em segregar as boas sementes das más, uma vez que o desenvolvimento da atividade açucareira exigia cada vez mais escravos e a escassez dos nativos era cada vez mais evidente, seja pelas fugas para o distante sertão ou pela ação dos inacianos. A obra de Fernão Cardim (1881, p. 333-334), cuja elaboração acredita-se ter ocorrido na década de 1580, atesta que na Capitania de Pernambuco existia muita escravaria da Guiné, enquanto que os índios da terra já eram poucos ${ }^{5}$.

Constatam-se, nessa época, aproximações do termo Tapuia a questões que envolvem a escravidão. Padre Anchieta (1933, p. 302), por exemplo, preocupado com a estruturação das aldeias jesuítas, não tem dúvida de que a palavra Tapuia quer dizer "escravos, porque todos os que não são de sua nação têm por tais e com todos têm guerra".

Explicação similar pode-se encontrar na obra do colono Gabriel Soares de Souza (SOUZA, 1851, p. 350 -351), para quem os tapuias eram tantos e tão divididos em bandos, costumes e linhagens que era difícil distinguir. De um modo geral, tapuias seriam "os contrários de todas as outras nações do gentio". Gente muito diversa, mas que o autor, lançando mão dos seus próprios

\footnotetext{
${ }^{4}$ Ver fac-símile da bula papal, transcrita para o espanhol, em: <https://jorgecaceresr.files.word press.com/2010/05/breve-sublimis-deus-paulo-iii.pdf $>$. Acesso em: 6 nov. 2016.

${ }^{5}$ Vainfas defende que a migração dos índios para o litoral e, após o incremento da escravização e da catequese, deste para o "sertão", foi também estimulada por uma lenda indígena que falava de um lugar mítico e que foi traduzido como "Terra sem Males" (VAINFAS, 1995, p. 42).
} 
interesses, não hesita em chamar a todos de "folgazões" porque não plantavam nem tinham roças, além de, paradoxalmente, servirem-se dos prisioneiros como escravos, os quais os vendem agora aos portugueses.

Com relação à língua, as abordagens são muito mais significativas, pois, conforme cita Todorov (1996, p. 120), "a língua sempre foi a companheira do império". No caso de Portugal, essa questão é ainda mais relevante quando lembramos que o latim vulgar, falado na Galiza e na Lusitânia, acabou sendo fundamental para diferenciar a nova nação que surgia ao sul do rio Minho. Embora Ameal (1974, p.47) admita que o idioma não tenha sido o elemento único na formação do Estado Português, conclui que ele estaria no mesmo patamar de importância de outros fatores, como as diferenciações geográficas e étnicas. E todos esses atributos teriam sido determinantes para os longos séculos de enfrentamento aos poderosos vizinhos. Tanto que Santos (1998, p. 147) concorda com Agostinho Silveira, quando este afirma que "o que Portugal fez de maior no mundo não foi nem o descobrimento, nem a conquista, nem a formação de nações ultramarinas: foi ter resistido a Castela”. O fato é que o pertencimento linguístico continuaria marcando a identidade da sociedade portuguesa em pleno século XX, a ponto de inspirar o poeta Fernando Pessoa (PESSOA, 1995, p. 358) a declarar: “minha pátria é a língua portuguesa”. Uma língua originária dos romanos, do mundo civilizado, e não dos povos bárbaros.

Esse sentido é precioso para entendermos como o fator linguístico esteve sempre associado à definição dos índios brasileiros como "bárbaros" pelos portugueses.
Diz-nos Todorov (2010, p. 24-25) que a palavra "bárbaro" foi cunhada pelos gregos antigos para determinar os limites da influência da sua língua, denominando assim os estrangeiros que não sabiam falar ou não a compreendiam direito.

Hansen (1998, p. 352) lembra que os romanos passaram a utilizar o termo para designar os germanos, os que balbuciavam uma língua não civilizada, mas que também os enfrentavam belicamente.

Na Idade Média, a influência de Aristóteles sobre pensadores católicos, como Alberto Magnus e Tomás de Aquino, fez com que a palavra "barbarus" se assemelhasse a "paganus", servindo, séculos mais tarde, para definir os povos ainda não convertidos (RAMINELLI, 1996, p. 54).

Porém, se esse sentido linguístico resistiu e atravessou o Atlântico com os conquistadores europeus, a cultura da guerra não esteve ausente dessa interpretação. Para Hansen (1998, p. 352), a associação do termo Tapuia ao Bárbaro, no Brasil, resulta também da intensa resistência à "civilização portuguesa" por parte de vários povos indígenas.

Cabe ressaltar que uma associação específica entre Tapuia e ferocidade, ou seja, que considere estes mais ferozes que os tupis, deve ser inteiramente afastada. Conforme Couto (1998, p. 98), a guerra era o mecanismo de reprodução social e de manutenção do equilíbrio cosmológico indígena, de maneira que "todos os grupos locais com quem não existissem laços de aliança eram considerados inimigos". Dentro dessa lógica, os próprios tupis aliados haviam expulsado da costa vários povos contrários que, derrotados, migraram para o interior, alguns dos quais os cronistas consideraram até mais mansos ${ }^{6}$.

\footnotetext{
${ }^{6}$ Almeida propõe a desconstrução da ideia de oposição rígida entre índios mansos e selvagens, pois era tanto vaivém de alianças e confrontos com grupos étnicos nas guerras quinhentistas, incluindo situações em que tupis e tapuias podiam agir como aliados ou inimigos, que deixavam os conquistadores, ainda sem dominar a lógica cultural dos índios, completamente perplexos. A autora defende, inclusive, o abandono da ideia "da existência de uma guerra geral dos índios bárbaros contra o império português", o que constituiria um olhar colonizador (ALMEIDA, 2010, p. 47 e 62-64).
} 
Para o Padre Anchieta (1933, p. 302), os tapuias expulsos para os matos não comiam carne humana e "mostravam-se muito amigos dos Portugueses", acrescentando que, apenas por terem uma natureza inquieta, não podendo estar muito tempo em um mesmo lugar, tornavam-se de difícil conversão. Na mesma linha, Gândavo (2004, p. 167) afirma que os tapuias não comem a carne de nenhum contrário e até perseguem aqueles que a costumam comer. Souza (1851, p. 18), por sua vez, garante que os tapuias são "gente branda e mais tratável e doméstica que o mais gentio que há na costa do Brasil".

Adiante, porém, Gabriel Soares de Souza resume bem melhor a complexidade da situação ao dizer que os

Tapuias são tantos e estão divididos em bandos, costumes e linguagem [que], para se poder dizer deles muito, era necessário de propósito e de vagar tomar grandes informações de suas divisões, vida e costumes; mas pois ao presente não é possivel (SOUZA, 1851, p. 350).

Eis que se tratava de uma diversidade cultural tão imensa, que Fernão Cardim (CARDIM, 1881, p. 194-206), depois de relacionar 76 povos "tapuyas", "nações bárbaras" que, de tantas, "parecia impossível poderem-se extinguir", conclui desanimado que as únicas coisas que os faziam semelhantes eram "por serem muito andejos e terem muitas e diferentes línguas dificultosas", o que, consequentemente, impedia a conversão.

Em contraponto, o religioso procura valorizar e hierarquizar a língua-geral, a única que ele entende alguma coisa, elogiando até a sua qualidade sonora, mas lamentando ainda assim as suas muitas variações:
Em toda esta província há muitas e várias nações de diferentes línguas, porém uma é a principal que compreende algumas dez nações de índios: estes vivem na costa do mar, e em uma grande corda do sertão, porém são todos estes de uma só língua ainda que algumas palavras discrepem e esta é a que entendem os Portugueses; é fácil, e elegante, e suave, e copiosa, a dificuldade dela está em ter muitas composições (CARDIM, 1881, p. 194).

Gândavo (2004, p. 135) foi bem mais prático e aplicou um modelo dual aos outros bárbaros: “A língua de que usam, por toda a costa, é uma [porém] há outra gentilidade de que nós não temos tanta notícia, que fala já outra língua diferente".

Mais uma vez Gabriel Soares de Souza (SOUZA, 1851, p. 58-59) demora-se falando sobre os Aimorés, descendentes dos "tapuias" e que estavam exercendo uma ousada resistência na região de Porto Seguro e Ilhéus, afirmando que eles eram considerados pelos bárbaros "por mais que bárbaros". Depois, atribuem-lhes os mais negativos valores europeus: só descem à costa para dar assaltos; não vivem em casas ou aldeias como os outros, mas andam sem rumo e dormem no chão sobre folhas; não fazem roça nem plantam, mantendo-se de frutos silvestre e da caça que matam, cuja carne comem crua ou mal assada; vivem de saltear toda a sorte de gentios que encontram; são traiçoeiros e não enfrentam o oponente de rosto a rosto, utilizando-se de ciladas e emboscadas; fogem cada um para sua parte se são enfrentados; ficam escondidos até que passem os que os seguem, para atirarem-lhes as flechas pelas costas; por fim, comem carne humana como mantimento. Por temor deles, as fazendas e engenhos da região estariam quase despovoadas. E qual a origem de povo tão terrível? O cronista tem uma explicação babeliana ${ }^{7}$ : por

\footnotetext{
${ }^{7}$ A associação entre acontecimentos locais e eventos bíblicos foi percebida também por Hansen (1998, p. 352) não somente nas obras dos cronistas religiosos, mas igualmente nas dos leigos, inclusive na do próprio Gabriel Soares de Sousa.
} 
terem sido expulsos da costa pelos contrários, passaram muitos anos sem verem outra gente "e os que destes descenderam vieram a perder a linguagem, e fizeram outra nova que não se entende de nenhuma outra nação do gentio de todo este estado do Brasil".

Esta regra simplificava bastante a tarefa dos catequizadores e dos escravizadores, uma vez que a "língua-geral", ou "abanheenga", estruturada desde a chegada do jovem José de Anchieta ao Brasil (SALVADOR, 1918, p. 143), poderia bem servir de parâmetro para a colheita de almas e de homens.

Uma profecia asteca pré-colombiana dizia: “Aqueles que não puderem compreender morrerão, os que compreenderem viverão" (TODOROV, 1996, p. 74). Creio que essa regra poderia adequar-se também aos índios brasileiros, uma vez que os "tapuias", aqueles povos falantes da "não-língua", ou seja, que não compreendiam a língua-geral, cabiam ser escravizados ou esquecidos, o que, afinal, constituem duas formas de perecer.

\section{A nação dos sem nação}

O IHGB foi criado no Rio de Janeiro, em 1838, sobre a proteção e financiamento do imperador e, apesar de teoricamente mostrar-se neutro em relação às disputas político-partidárias, seus participantes eram escolhidos por indicação, sendo que a maioria desempenhava funções burocráticas no Estado. O projeto historiográfico do Instituto incluía uma releitura do passado que legitimasse o presente, não estando isento, obviamente, de um sentido político. Nesse aspecto, estudos etnográficos, arqueológicos e linguísticos deveriam apontar para os lugares sociais dos brasileiros, inclusive o das populações indígenas.
Para os intelectuais reunidos em torno do IHGB, desenhar um rosto para a Nação brasileira não constituía tarefa simples: como categorizar uma cultura heterogênea, formada por brancos, mulatos, pretos livres, escravos e índios de diferentes origens?

Conforme Guimarães (1998, p. 6-14), para uma historiografia elitista, próxima à tradição iluminista, a solução adotada foi reconhecer o Brasil monárquico como uma continuidade da civilização portuguesa e europeia. Na verdade, uma "frente avançada da civilização francesa dos trópicos”. Dessa forma, enquanto no plano externo "os outros" passaram a ser as repúblicas vizinhas latino-americanas decadentes, a representação da "barbárie" interna coube aos negros e índios, os quais deveriam ser simplesmente excluídos do projeto de construção nacional.

Reis (2007, p. 26) argumenta que o projeto do IHGB, no aspecto geográfico, buscava reconhecer os atributos físicos e engrandecer a natureza brasileira e, no campo histórico, procurava "eternizar os fatos memoráveis da pátria e salvar do esquecimento os nomes dos seus melhores filhos".

Almeida concorda com tal pensamento ao afirmar que a intenção do IHGB era, de fato, "criar uma história do Brasil que unificasse a população do novo estado em torno de uma memória histórica comum e heroica [reservando] aos índios um lugar muito especial: o passado" (ALMEIDA, 2010, p. 17) .

O homme de lettres que assumiu o comando da missão de estabelecer a identidade brasileira como herdeira da civilização lusitana foi Francisco Adolfo Varnhagen, cuja obra, História Geral do Brasil (VARNHAGEN, 1854, p. 1-12), começa justamente com um voo pela origem da civilização ocidental na Grécia antiga, passando depois pela formação das nações europeias, forjadas no cadinho iluminista francês, 
e, graças aos feitos dos reis e heróis portugueses, tudo isso finalmente atravessa o oceano para formar a civilização dos trópicos. Os índios, diferentemente dos brancos, "não conheciam as delícias do amor da pátria, porque, nômades, pátria não tinham” (VARNHAGEN, 1854, p. 103).

Ao contrário de diferenciar os índios, Varnhagen procurou unificá-los, tratando a todos com o mesmo desprezo. Para Reis (2007, p. 35), Varnhagen via os índios como uma só raça, falando dialetos de uma só língua. Assim, Tapuia e outros tantos nomes não passavam de apelidos, às vezes até insultos, que os primeiros cronistas não conseguiram perceber:

Fique, pois, entendido que nenhum crédito merece todos esses catálogos de nomes bárbaros e dissonantes, com que se tem pretendido distinguir os habitantes de um distrito pelas alcunhas, ás vezes duplas e até múltiplas, com que já estes, já aqueles vizinhos, os apelidavam, geralmente por injúria ou vitupério; poucas vezes por honra ou apreço (VARNHAGEN, 1854, p. 103).

Defende Varnhagen que "Tapuy" quer dizer apenas "o estrangeiro" ou "o bárbaro", definição que corrobora com a sua preocupação em negar qualquer estrutura social indígena que se aproximasse do conceito de nação. Diz ele que uma ideia equivocada dos primeiros colonos foi levada adiante pelos escritores e na qual muitos ainda acreditam: a da existência de uma grande nação Tapuya. Para ele, o verdadeiro sentido da palavra Tupi é igualmente duvidoso, podendo significar tão somente "tio", sem ligação com país nenhum (VARNHAGEN, 1854, p. 104).

Em nota à obra de Gabriel Soares de Souza, Varnhagen beira o desespero ao propor: "Não havia, e insistimos ainda nesta ideia, no Brasil, nação Tapuia. Esta palavra quer dizer contrário, e os indígenas a aplicavam até aos franceses, contrários dos nossos, chamando-lhes Tapuytinga, isto é, Tapuia branco" (SOUZA, 1851, p. 406).
Para Guimarães (1998, p. 12), a busca dos que faziam o IHGB em argumentar "cientificamente" a superioridade branca acabou provocando um debate acirrado no campo da literatura, na qual a imagem romântica do indígena era veiculada como portadora da brasilidade. Conforme o autor, Varnhagen "viria a se posicionar radicalmente contra o projeto do romantismo literário de transformar o indígena em representante da nacionalidade brasileira".

Entretanto, verifica-se que, talvez para melhor enfrentar a tentativa do IHGB de minimizar a importância dos povos indígenas, reduzindo-os a um único grupo, a literatura romântica não consegue escapar da visão dual das linhagens nativas inaugurada pelos primeiros cronistas.

O romance Ubirajara, de José de Alencar (1996), é particularmente interessante porque situa a narrativa em uma época pré-cabraliana e, afora a tentativa frustrada de recriar a sociedade indígena, onde os embates dos guerreiros nas selvas mais parecem saídos de um romance medieval de cavalaria, o autor elabora uma lenda criacionista para o Brasil onde "nações" em desavenças, utilizando o instrumento do matrimônio, resolvem suas diferenças e alcançam a paz. Essa proposta, apesar de fantasiosa e aderente à posição do romancista na sociedade escravocrata e patriarcal do Império, irrita os teóricos do IHGB, defensores do "branqueamento" da população, porque, mesmo não citando os negros, propõe o reconhecimento, ainda que equivocado, das "tradições da pátria indígena".

No romance, Alencar tem o cuidado de construir duas hipotéticas "nações" indígenas rivais, "Araguaia" e "Tocantim", para passar uma presumida isenção de sua parte. Tal pretensão desaparece logo nas primeiras linhas, onde o herói protagonista surge na figura de um jovem caçador, candidato a guerreiro, destacando-se no embate com um oponente de outra tribo. 
De qualquer maneira, percebe-se que as duas "nações" envolvidas, apesar de momentaneamente não aliadas, comungam do mesmo brio e honradez, sugerindo a mesma origem Tupi. Essa constatação fica mais forte quando é o próprio guerreiro desafiante que, comunicando a sua disposição para a luta, diz: "Há três luas, desde que fugiram espavoridos os bárbaros tapuias, que Pojucã não combate" (ALENCAR, 1996, p. 18). É particularmente curioso como Alencar termina caindo na idêntica tentação dos primeiros cronistas de hierarquizar e classificar como inferior uma parte dos indígenas. Nas notas explicativas, o romancista torna ainda mais clara a aproximação do seu ponto de vista com os constructos elaborados no século XVI:

Tapuia: De 'taba' e 'puir' - o que foge das tabas. Davam os indigenas esse nome a povos mais bárbaros e de língua diversa. Segundo as últimas investigações etnológicas, pertenciam esses povos a uma raça diversa da tupi, e muito aproximada, senão congênere, do tipo mongólico. Entretanto, Orbigny, 'L'homme américain', sustenta a identidade das duas raças, tapuia e tupi (ALENCAR, 1996, p. 78).

Alencar consegue reunir para Tapuia os significados de escravo ("o que foge"), o mais bárbaro e o de língua diversa, nada diferente do que havia sido proposto antes. Entretanto, chama a atenção o fato de ele recorrer à ciência para negar uma possível "brasilidade" desses povos, separando-os dos tupis e associando-os aos mongóis. De qualquer forma, ao final, ele deixa entreaberta a porta da hipótese das duas raças.

O historiador e poeta Baptista Caetano de Almeida Nogueira, em nota à obra de Fernão Cardim (CARDIM, 1881, p. 267), tenta jogar um pouco de luz à questão, mas parece ter lançado muito mais sombras. Ele começa aproximando o termo Tapuia à escravidão, como os primeiros cronistas, pois a palavra seria com- posta de "tapy-eyi", que significaria "dos comprados, dos aprisionados, dos cativos". Entretanto, reconhece que poderia também ter origem em coisas tão díspares como "a plebe do povo", "cabana ou casa pequena", ou simplesmente "folha".

Tais interpretações atravessaram séculos e ainda influenciam a historiografia atual. Nas notas ao livro de Gândavo (2004, p. 167), Hue e Menegaz afirmam que o menosprezo dos portugueses pelos tapuias teria sido transmitido pelos povos tupis-guaranis e arriscam que tal palavra quer dizer "aqueles que falam a língua travada ou selvagens", conclusão certamente retirada dos "Prolegômenos ao Livro I", de Frei Vicente Salvador (SALVADOR, 1918, p. 9).

Por sua vez, o editor do referido livro de Gândavo, em edição posterior, mas em nota ao mesmo trecho da narrativa, busca um possível ponto de aproximação entre os pensamentos de Cardim e Varnhagen: "É difícil dizer ao certo o que designa a palavra 'tapuia', pois o termo indicaria apenas aqueles que não falam a mesma língua [...]. Parece mesmo um termo genérico para indicar 'os outros"” (GÂNDAVO, 2008, p. 141).

O que fica de tudo isso é que os constructos propostos no século XVI foram ressignificados no século XIX, sendo refutados ou acatados, de maneira que muitos desses entendimentos tornaram-se conceitos que chegaram até aos nossos dias.

\section{Conclusões}

Até meados dos anos setecentistas, as mudanças ocorriam tão lentamente que o futuro estava ligado inteiramente ao passado, ainda mais que "a revelação bíblica, gerenciada pela Igreja, envolvia de tal forma a tensão entre experiência e expectativa que elas não podiam separar-se" (KOSELLECK, 2006, p. 315) ${ }^{8}$.

\footnotetext{
${ }^{8}$ A partir desse ponto, todas as referências à Koselleck estão relacionadas ao texto: "Espaço de Experiência e horizonte de expectativa: duas categorias históricas", in: Futuro Passado. Cap. 14, 2006, p. 305-327.
} 
Conforme constatamos no presente estudo, até os cronistas laicos do século XVI enxergavam a realidade através do prisma religioso. Por sua vez, as decisões da Igreja assumiam a condição de verdade única.

Esse suporte religioso foi decisivo na tentativa de compreensão de uma realidade histórica, por parte dos cronistas, na qual experiência e expectativa estavam sendo conjuntamente construídas e participavam de um mesmo processo: a captura de indígenas para a catequização ou a escravidão.

É importante perceber que, em tal circunstância, quando a leitura histórica assumia importância fundamental no encaminhamento a ser dado às práticas de ocupação do novo território, o termo "Tapuia" ganhou autonomia e foi isolado e utilizado para a denominação genérica dos índios inimigos, tornando-se algo sem passado e sem interesse no presente.

Retomando Koselleck, a modernidade, inaugurada no século XVIII, substituiu a profecia pelo prognóstico e pelo progresso. $\mathrm{O}$ vivido não conseguia mais responder às novas aspirações e a ciência se encarregava de ampliar cada vez mais o panteão de novidades. Se existia uma única história fluindo em uma única direção, deveria existir também um único futuro, de maneira que a busca frenética por atingi-lo provocava o distanciamento progressivo do passado e cujo grau de afastamento tornava-se parâmetro para a própria ação empreendida. Tudo isso ocasionou uma desvinculação da expectativa em relação à experiência, passando esta a ter menos importância que aquela.

Em nossa análise, a visão dos hommes de lettres do IHGB, em meados do século XIX, mostrava-se, de fato, voltada para o porvir, devendo o passado ser resgatado, mas com as devidas ressalvas e críticas. Naquele momento, em que o horizonte de expectativa se separava do espaço de experiência, o termo "Tapuia", em sentido contrário, se fundia com outras denomina- ções, uma vez que todas elas pertenciam a um mesmo passado, o qual deveria ser apressadamente superado. Não mais bastava distinguir estaticamente os povos entre superiores e inferiores, entre civilizados e bárbaros, era agora necessário o contínuo progresso das civilizações para que o mundo fosse aperfeiçoado e conduzido à iluminação, tudo isso mediado pela razão humana.

Uma característica desse novo tempo histórico, ainda conforme Koselleck, é justamente essa suposta graduação civilizatória dos povos, de maneira que os que estivessem "à frente" achavam-se no direito de julgar os demais. Varnhagen, como vimos, coloca-se não apenas em patamar de superioridade em relação aos cronistas do passado e aos seus contemporâneos românticos, mas também com capacidade de atestar a condição superior da monarquia brasileira em comparação aos vizinhos Estados republicanos.

Não surpreende que a literatura romântica, que reclamava justamente do progresso desenfreado promovido pela modernidade e que buscava um futuro não tão modificado, tivesse uma relação mais próxima com o passado a ponto de construir uma imagem idílica do índio como elemento fundador da "nação brasileira". Com isso, o termo "Tapuia" separa-se novamente do “Tupi”, visto ter sido este último o escolhido para representar o papel da "raça brasílica".

Quando lidamos com memórias alheias, diz-nos Koselleck, passado e futuro jamais coincidem. No caso do uso do relato dos cronistas, pelos intelectuais do IHGB e pelos literatos românticos brasileiros do século XIX, tal afirmação fica bem evidente. A maneira como essas memórias foram recolhidas, revisadas e utilizadas mostrou-se diretamente associada ao horizonte de expectativa específico de cada parte interessada. Conforme resume Hartog (2015, p. 60), trata-se de "outros tempos, outros costumes, outras histórias, outros regimes de historicidade". 
Parece-nos importante concluir que, antes que tentemos entrar nas cabeças dos índios brasileiros do século XVI para decifrar o que eles queriam dizer com "Tapuia”, busquemos entender um pouco mais como os cronistas e historiadores lidaram com o termo ao longo do tempo. Para Jenkins (2001, p. 68-78), é muito mais possível estabelecermos alguma empatia com as mentes dos escrevinhadores do passado do que com as intenções dos personagens que eles descrevem. Tal exercício, em suma, contribui para não incorrermos no erro de tomarmos memórias como a mais pura realidade.
Porém, o que significa exatamente a palavra Tapuia? Mais uma vez Koselleck vem nos socorrer ao afirmar que "na investigação existem situações em que o abster-se de perguntas sobre a gênese histórica pode aguçar mais o olhar que se dirige à própria história". Portanto, se por um lado a análise da palavra Tapuia contribui para desconstruir as generalizações e o dualismo com que foram pensados os índios brasileiros pela historiografia tradicional, por outro, apresenta-se como uma chave para melhor entendermos o tempo histórico em mutação.

\section{Referências}

ALENCAR, José de. Ubirajara. São Paulo: Ática, 1996, 94 p.

ALMEIDA, Maria Regina Celestino de. Os Índios na História do Brasil. Rio de Janeiro: FGV, 2010, 168 p.

AMEAL, João. História de Portugal: das origens a 1940. 7. ed. Porto: Tavares Martins, 1974, 846 p.

BORGES, Jorge Luís. O idioma analítico de John Wilkins. In: Outras Inquisições. Tradução de Davi Arrigucci Jr. São Paulo: Companhia das Letras, 2007, pp. 121-126.

CAMINHA, Pero Vaz de. A Carta de Pero Vaz de Caminha. Brasília: MEC, s.d. 14 p. Disponível em: http:// objdigital.bn.br/Acervo_Digital/Livros_eletronicos/carta.pdf. Acesso em: 23 fev. 2014.

CARDIM, Fernão. Tratado da Terra e Gente do Brasil. Rio de Janeiro: J. Leite \& Cia, 1881, 435 p. Disponível em: 247. Acesso em: 23 fev. 2014.

CORDEIRO, Cecília Siqueira. Historiografia e história da historiografia: alguns apontamentos. In: Anais do XVIII Simpósio Nacional de História, 2015. Disponível em: /1/mode/1up" http:/www.snh2015.anpuh.org/resources/ anais/39/1428357432_ARQUIVO_ArtigoSNH2015Historiografia.pdf. Acesso em 31 out. 2016.

COUTO, Jorge. A Construção do Brasil: ameríndios, portugueses e africanos, do início do povoamento a finais de Quinhentos. Lisboa: Cosmos, 1998, 408 p.

DE CERTEAU, Michel. A Operação Historiográfica. In: A Escrita da História. Cap. II. Tradução de Maria de Lourdes Menezes. 3. ed. Rio de Janeiro: Forense, 2013, p. 45-111.

GARCIA, Rodolpho. Introducção. In: Tratados da Terra e Gente do Brasil. CARDIM, Fernão. Rio de Janeiro: J. Leite \& Cia, 1925. Disponível em: http://www. brasiliana.usp.br/bbd/handle/1918/02119000\#page/1/mode/1up. Acesso em: 23 fev. 2014.

GÂNDAVO, Pero de Magalhães de. A Primeira História do Brasil: história da província Santa Cruz a que vulgarmente chamamos Brasil. Modernização do texto original de 1576 e notas de Sheila Moura Hue e Ronaldo Menegaz. Rio de Janeiro: Zahar, 2004, 207 p.

. História da província Santa Cruz. Organização, introdução e notas de Ricardo Martins Valle e Clara Carolina Souza Santos. São Paulo: Hedra, 2008, 156 p.

GUIMARÃES, Manoel Luís Salgado. Nação e Civilização nos Trópicos: o Instituto Histórico e Geográfico Brasileiro e o projeto de uma História Nacional. Revista Estudos Históricos,

n. 1. Rio de Janeiro: CPDOC/FGV, 
1988, p. 5-27. Disponível em: http://biblioteca digital.fgv.br/ojs/index.php/reh/article/download/ 1935/1074. Acesso em: 5 nov. 2016.

FAUSTO, Carlos. Fragmentos de História e Cultura Tupinambá. In: História dos Índios do Brasil. CUNHA, Manuela Carneiro da (Org.). São Paulo: Companhia das Letras, 1992, p. 381-396.

FOUCAULT, Michel. As palavras e as Coisas: uma arqueologia das ciências humanas. Tradução de Salma Tannus Muchail. 8. ed. São Paulo: Martins Fontes, 2000, 544 p.

HANSEN, João Adolfo. A Servidão Natural do Selvagem e a Guerra Justa Contra o Bárbaro. In: A Descoberta do Homem e do Mundo. NOVAES, Adauto (Org.). São Paulo: Companhia das Letras, 1998, p. 347-373.

HARTLEY, L. P. O Mensageiro. Tradução de Paulo Cézar de Mello. São Paulo: Nova Fronteira, 2002, 248 p.

HARTOG, François. Tempo, história e a escrita da história: a ordem do tempo. In: Revista de História (USP), n. 148. São Paulo: USP, 2013, p. 9-34. Disponível em: http://www.revistas.usp.br/revhistoria/article/ view/18952/21015. Acesso em 31 out. 2016.

. Regimes de Historicidade: presentismo e experiências do tempo. Tradução de Andréa Souza de Menezes et alii. Belo Horizonte: Autêntica, 2015, 267 p.

JENKINS, Keith. Algumas perguntas e algumas respostas. In: A história repensada. São Paulo: Contexto, 2001, p. 53-91.

KOSELLECK, Reinhart. Futuro Passado: contribuição à semântica dos tempos históricos. Tradução de Wilma Patrícia Maas e Carlos Alberto Pereira. Rio de Janeiro: Contraponto/PUC-Rio, 2006, 368 p.

NOVAES, Adauto. Experiência e Destino. In: A Descoberta do Homem e do Mundo. São Paulo: Companhia das Letras, 1998, p. 7-16.

PADRE ANCHIETA. Cartas, Informações, Fragmentos Históricos e Sermões do Padre Joseph de Anchieta, S. J. (1554-1594). Rio de Janeiro: Civilização Brasileira, 1933. Disponível em: <http://www.brasiliana.usp.br/bbd/ handle/1918/00381630\#page/1/mode /1up>. Acesso em: 23 fev. 2014.

PESSOA, Fernando (Bernardo Soares). Livro do Desassossego. 2. ed. São Paulo: Brasiliense, 1995, 402 p.

REIS, José Carlos. As Identidades do Brasil: de Varnhagem a FHC. 9. ed. Rio de Janeiro: FGV, 2007, 280 p.

. O tempo histórico como "representação intelectual". In: Revista do Patrimônio Histórico e Artístico Nacional, n. 34. Brasília: IPHAN/MinC, 2012, p. 45-65.

RUBIOS, Juan López de Palacios. Notificación y requerimiento que se há dado de hacer a los moradores de las islas en tierra firme del mar océano que aún no están sujetos a Nuestro Señor, 1513. Disponível em: http:// www.4shared.com/web/preview/doc/BAj2CQWM. Acesso em: 19 jan. 2014.

SALVADOR, Frei Vicente do. História do Brasil (1500-1627). São Paulo: Weiszflog Irmãos, 1918. Disponível em: http://www.brasiliana.usp.br/bbd/handle/1918/01861600\#page/1/mode/1up. Acesso em 23 fev. 2014.

SANTOS, João Marinho dos. A Expansão pela Espada e pela Cruz. In: A Descoberta do Homem e do Mundo. NOVAES, Adauto (Org.). São Paulo: Companhia das Letras, 1998, p. 145-162.

SILVA, Francisco Carlos Teixeira da. Conquista e Colonização da América Portuguesa: o Brasil colônia 1500/1750. In: LINHARES, Maria Yedda (Org.). História Geral do Brasil. 9. ed. Rio de Janeiro: Elsevier, 1990, p. 33-94.

SOUZA, Gabriel Soares de. Tratado Descritivo do Brasil. Rio de Janeiro: Typographia Universal de Laermmert, 1851. Disponível em: http://www.brasiliana.usp.br/bbd /handle/1918/01720400\#page/9/mode/1up. Acesso em 23 fev. 2014. 
TODOROV, Tzvetan. A Conquista da América: a questão do outro. Tradução: Beatriz Perrone Moisés. São Paulo, Martins Fontes, 1996, 263 p.

. O Medo dos Bárbaros: para além do choque das civilizações. Tradução: Guilherme João de Freitas Teixeira. Petrópolis: Vozes, 2010, p. 237.

VAINFAS, Ronaldo. A Heresia dos Índios: catolicismo e rebeldia no Brasil colonial. São Paulo: Companhia das Letras, 1995, $275 \mathrm{p}$.

VARNHAGEN, Francisco Adolfo. História Geral do Brazil. Tomo I. Rio de Janeiro: E. H. Laemmert, 1854,496 p. Disponível em: http://www.brasiliana.usp.br/bbd /handle/1918/01818710\#page/8/mode/1up. Acesso em 23 fev. 2014.

Submissão: 17/07/2017 Aceite: 07/09/2017 